\title{
Magnitude of Helicobacter pylori among Dyspeptic Patients Attending at University of Gondar Hospital, Gondar, Northwest Ethiopia
}

\author{
Desie Kasew $^{1 * \odot}$, Ashenafi Abebe ${ }^{1}$, Ufaysa Munea ${ }^{1}$, Tekalign Deressa ${ }^{2}$, \\ Yalewayker Tegegne ${ }^{3}$, Martha Alemayehu ${ }^{4}$, Mulugeta Melku ${ }^{5 \odot}$
}

\footnotetext{
OPEN ACCESS

Citation: Desie Kasew, Ashenafi Abebe, Ufaysa Munea, Tekalign Deressa, Yalewayker Tegegne, Martha Alemayehu, Mulugeta Melku. Magnitude of Helicobacter pylori among Dyspeptic Patients Attending at University of Gondar Hospital, Gondar, Northwest Ethiopia. Ethiop J Health Sci.2017;27(6):571.

doi:http://dx.doi.org/10.4314/ejhs.v27i6.2

Received: May 19, 2017

Accepted: May 26, 2017

Published: November 1, 2017

Copyright: () 2017 Desie Kasew, et al

This is an open access article distributed under the terms of the Creative Commons

Attribution License, which permits unrestricted use, distribution, and reproduction in any medium, provided the original author and source are credited.

Funding: Nil

Competing Interests: The authors declare that this manuscript was approved by all authors in its form and that no competing interest exists.

Affiliation and Correspondence:

${ }^{1}$ Department of Medical Laboratory

Sciences, College of Medicine and

Health Sciences, University of Gondar, Ethiopia

${ }^{2}$ Department of Immunology and

Molecular Biology, College of

Medicine and Health Science,

University of Gondar, Gondar,

Ethiopia

${ }^{3}$ Department of Medical Parasitology,

College of Medicine and Health

Sciences, University of Gondar, Ethiopia

${ }^{4}$ Department of Medical

Microbiology, College of Medicine

and Health Sciences, University of

Gondar, Ethiopia

${ }^{5}$ Department of Hematology and

Immunohematology, College of

Medicine and Health Sciences,

University of Gondar, Ethiopia

*Email:

dessalegnkassaw83@gmail.com

ABSTRACT
}

BACKGROUND: Helicobacter pylori (H.pylori) infection is predominantly acquired in childhood from family members. The infection can cause dypepepsia, chronic and acute gastritis and gastric cancer. Dyspepsia is the most common illness in the Ethiopian population visiting outpatient department of health facilities, and it has also been associated with H.pylori infection. The aim of this study was to assess the magnitude of H.pylori and its associated factors among dyspeptic patients who visited University of Gondar Hospital Outpatient Department.

MATERIALS AND METHODS: An institutional-based crosssectional study was conducted on 354 dyspeptic patients. A systematic random sampling technique was employed to select study participants. Data were collected by using structured questionnaire via face-to-face interview. H.pylori infection was diagnosed using stool antigen test method. The data were entered into Epi info version 3.5.3 and transferred to Statistical Package for Social Sciences version 20. Both Bivariable and multivariable binary logistic regression analyses were performed to see the effect of independent variables on the dependent variable.

RESULT: Of the total study participants, 201(56.8\%), 195(55.1\%) and $182(51.4 \%)$ were married, urban residents and females, respectively. The overall magnitude of H.pylori infection was 37.6\%. In bivariable logistic regression analysis, sex and marital status were significantly associated with H.pylori infection, but in multivariable logistic regression analysis only marital status was significantly associated with $\mathrm{H}$.pylori infection.

CONCLUSION: The magnitude of H.pylori infection is high indicating that it is a public health problem in the study to area. According to this study, none of the variables were significantly associated with H.pylori infection. Hence, effective preventive, control and screening strategies need to be designed to reduce the burden of the disease.

KEYWORDS: Associated factor, Dyspepsia, Helicobacter pylori

๑ These authors contributed equally to this work.

DOI: http://dx.doi.org/10.4314/ejhs.v27i6.2 


\section{INTRODUCTION}

Helicobacter pylori (H.pylori) is spiral shaped or curved rod gram-negative, micro-aerophilic with two to six lophotrichious flagella that gives it the motility to withstand rhythmic gastric contractions and penetrate the mucosa. The principal reservoir for $H$. pylori infection appears to be the stomach especially antrum (1). H.pylori infection is predominantly acquired in childhood from the family. The majority of infected people do not develop symptoms. However, the infection causes progressive damage to the lining of the stomach that may be irreversible. The infection always causes gastritis, which affects the gastric mucosa and may be associated with nausea (2). Chronic gastritis is primarily developed with H.Pylori colonization. The bacterium is also linked to the development of gastric ulcers, duodenal ulcers and stomach mucosal atrophy. Moreover, H.pylori is considered to be the leading carcinogen because chronic inflammation and atrophy can further lead to malignant transformation $(3,4)$.

There are different factors that allow $H$. pylori to colonize and survive in harsh gastric environment of the host. Of these, the ability of the bacteria to produce large amounts of unease which hydrolyzes urea to ammonia and carbon dioxide, the presence of flagella which allow the bacteria to move, navigate, and persistently colonize the mucus layer of the gastric epithelium, and the ability of the bacteria to produce enzymes that break down the surfactant layer over the gastric epithelium which allows the bacteria to access nutrition are the major contributing factors of H.pylori pathogenesis (5).

H.pylori is one of the most common infectious diseases encountered in developing and developed countries (6). According to the World Gastroenterology Organization report, the prevalence of H.pylori in developed countries ranges from $20-50 \%$. The infection has a higher prevalence rate in developing countries (80-95\%). In Ethiopia, the prevalence is as high as $48 \%$ in children aged 2-4 year, $80 \%$ at the age of 6 year, and above $95 \%$ in adults $(7,8)$. The global prevalence of H.pylori infection is more than 50\% with significant variation within and among countries. Sero-prevalence studies in different countries show that the epidemiology of the infection varies with the geographic location, ethnicity and demographic factors of the studied population. Furthermore, these studies reported that H.pylori sero-positivity rate increases progressively with age. Similarly, the rate of H.pylori infection can also be high in patients with stomach cancer; $75 \%$ of all stomach cancer cases are infected $(9,10)$. Differences in the rate of childhood acquisition of infection is probably responsible for the differences in the prevalence of infection between developed and developing countries. This could be due to disparities in socio-economic and living standards. High prevalence is an indication of a need for public health intervention (11).

No single factor can be the major determinant of $\mathrm{H}$. pylori incidence and prevalence. However, poverty-associated factors are found to be major risk factors (12). A study conducted in Gondar revealed that alcohol intake and age are risk factors for H.pylori infection, but socioeconomic status requires further investigation (13). In developing countries, the required health finance is unaffordable to properly manage H.pylori infection, which results in diseases including peptic ulcer and gastric cancer (9). Planning preventive measures that reduce the burden of H.pylori infection in the community has paramount importance. In doing so, evidences on the magnitude and associated factor of H.pylori infection in various localities are mandatory to design intervention measures. Hence, this study is aimed to investigate the magnitude and associated factors of H.pylori infection among dyspeptic patients at the Outpatient Department of University of Gondar Hospital.

\section{MATERIALS AND METHODS}

Study area: The study was conducted at University of Gondar Hospital Outpatient Department, Gondar Town, Northwest Ethiopia. The town is found at $740 \mathrm{~km}$ from the capital city,

DOI: http://dx.doi.org/10.4314/ejhs.v27i6.2 
Addis Ababa, and $180 \mathrm{~km}$ from the capital city of Amhara Regional state, Bahir Dar. It is located at an altitude of 2200 meter above sea level and has average temperature of $20^{\circ} \mathrm{C}$. The hospital provides teaching and referral services for more than 5 million people including inpatient and outpatient services. The study was conducted from March 1 to April 30, 2016.

Study population and sampling technique: Dyspeptic patients who attend at University of Gondar Hospital Outpatient Department during the study period and were willing to participate in the study were the study population. All dyspeptic patients who were clinically suspected for $H$. pylori infection and visited the outpatient department during the study period were included in the study. Patients who had been taking protonpump inhibitor or other antibiotics against $H$. pylori within the last 2 weeks before data collection period were excluded from the study. Systematic random sampling technique was employed to select the study participants from their sequence of hospital visits. A total of 354 study participants were included in the study.

Data collection and laboratory method: Data on socio-economic, demographic and behavioral characteristics of the study participants were collected using structured pre-tested questionnaire via face-to-face interview. Approximately 2 gram of stool sample was collected from each participant in a clean container. $H$. pylori stool antigen was detected by Wondfo one step H.pylori feces test kit (Guangzhou Wondfo Biotech, China) according to the manufacture`s instruction.

Data analysis and interpretation: Data was cleared, entered into Epi info version 3.5.3 and transferred to Statistical Package SPSS version 20 software for analysis. Descriptive and summary statistics were carried out. Both bivariable and multivariable binary logistic regression model were fitted to identify associated factors of H.pylori. Odds ratio, and $95 \% \mathrm{CI}$ for odds ratio were computed to assess the strength of association and statistical significance. Variables having $p$-value of less than 0.2 in the bivariable logistic regression analysis were fitted into the multivariable logistic regression model. Variables having p-value less than 0.05 in multivariable logistic regression model were considered to be statistically significant. The model fitness was checked by using Hosmore-lemeshow goodness of fit test.

Ethical consideration: The study was conducted after obtaining ethical clearance from the School of Biomedical and Laboratory Sciences. Official letter was submitted to the University of Gondar Hospital. The purpose of the study was explained for each study participant. The data was collected after informed consent was obtained from each study participant. The data was kept confidentially. The H.pylori stool antigen test results were communicated to the responsible physicians working at the outpatient department.

\section{RESULT}

Socio-demographic characteristics of study participants: A total of 354 dyspeptic patients were included in the study. About 201(56.8\%), $195(55.1 \%)$ and $182(51.4 \%)$ of the participants were married, urban residents and females, respectively. About 132(37.3\%) and 112(31.6\%) of the study participants were below the age of 26 years and in the age ranges of 26-40 years, respectively. Of the total participants, 119(33.6\%) and $105(29.7 \%)$ were educationally unable to read and write, and occupationally students, respectively. With regard to the family size, $143(40.4 \%)$ of them were living within the family having 1-4 members. About half of the participants had a family monthly income of less than 1000 Ethiopian Birr (Table 1).

Behavioral and hygiene practices of study participants: When we consider lifestyle and hygiene, 172(48.6\%) had been drinking alcohol; of those only $39(11 \%)$ had been drinking more than three times per week. Nearly $256(73.3 \%)$ of the subjects had habit of a hand washing both before meal and after visiting toilet, while the remaining $98(27.7 \%)$ were practicing either before meal or after visiting toilet. Seventy-one (20.1\%) and $93(26.3 \%)$ the study participants used water from well and open sources, respectively.

DOI: http://dx.doi.org/10.4314/ejhs.v27i6.2 
Table 1: Socio-demographic characteristics of dyspeptic patients attending at University of Gondar Hospital Outpatient Department, 2016.

\begin{tabular}{llcc}
\hline Variables & & Frequency & Percent \\
\hline Sex & Male & 172 & 48.6 \\
Age & Female & 182 & 51.4 \\
& $<=25$ & 132 & 37.3 \\
Residence & $26-40$ & 112 & 31.6 \\
& $>40$ & 110 & 31.1 \\
Marital Status & Urban & 195 & 55.1 \\
& Rural & 159 & 44.9 \\
Educational status & Married & 201 & 56.8 \\
& Unmarried & 153 & 43.2 \\
& Unable to read and write & 119 & 33.6 \\
Occupation & Primary and secondary education & 143 & 40.4 \\
& Tertiary Education & 92 & 26 \\
& Student & 105 & 29.7 \\
& Farmer & 59 & 16.7 \\
Monthly income & Housewife & 90 & 25.4 \\
in (ETB) & Government and private employee & 76 & 21.5 \\
& Others* & 24 & 6.8 \\
Family size & 1000 & 180 & 50.8 \\
& $>=3000-2999$ & 126 & 35.6 \\
& $1-4$ & 48 & 13.6 \\
& $5-6$ & 143 & 40.4 \\
& $>6$ & 120 & 33.9 \\
& $>$ & 91 & 25.7 \\
\hline
\end{tabular}

*Other occupation includes daily laborers, merchants and unemployed; Unmarried marital status includes single, divorced and widowed

Prevalence of H.pylori with respect to sociodemographic characteristics: The magnitude of H.pylori infection was assessed by considering the socio-demographic characteristics of the study participants. The study showed that high magnitude of H.Pylori infection was found in study participants who were male, 74(43\%). Lower magnitude was observed among participants aged greater than 40 years. Regarding educational status and family size, 60(42\%) of participants with primary or secondary educational attainment and 59(41.3\%) of participants with family size of $1-4$ members were positive for H.pylori (Table 3).
The magnitude of the infection was higher in participants who did not wash their hands both before meal and after toilet, 41(42\%), and got drinking water sometimes from protected water sources and mostly from open sources, 11(47.8\%). The positivity for H.Pylori infection in this study was similar between those who are alcohol consumers and those who do not use it (Table 4).

Factors associated with H.pylori infection: In bivariable binary logistic regression analysis, only sex was significantly associated with H.pylori infection. However, in multivariable binary logistic regression analysis, controlling the possible cofounders, it was not significantly associated with H.pylori infection (Table 5).

DOI: http://dx.doi.org/10.4314/ejhs.v27i6.2 
Table 2: Life style and hygiene related factors of dyspeptic patients who attended at University of Gondar Hospital Outpatient Department, 2016.

\begin{tabular}{llll}
\hline Variable & & Frequency & Percent \\
\hline Alcohol drinking & Yes & 172 & 48.6 \\
Habit & No & 182 & 51.4 \\
\hline Frequency of & Not drank & 182 & 51.4 \\
alcohol intake & 1 to 3 times & 133 & 37.6 \\
per week & $>3$ times & 39 & 11 \\
\hline Type of alcohol & Non-drinker & 182 & 51.4 \\
& Local alcohol & 119 & 36.6 \\
& Beverages & 21 & 5.9 \\
& Both & 32 & 9 \\
\hline Hand washing & Either before meal or after toilet & 98 & 27.7 \\
Habit & Both before meal and after toilet & 256 & 73.3 \\
\hline Hand washing habit & Always & 96 & 27.1 \\
With soap & Often & 70 & 19.8 \\
& Sometimes & 110 & 31.1 \\
& Never & 78 & 22 \\
\hline Water source & Protected Pipe & 167 & 47.2 \\
& Protected well & 71 & 20.1 \\
& Open sources & 93 & 26.3 \\
& Both protected and open source & 23 & 6.5 \\
\hline Habit of washing & Always & 175 & 49.4 \\
cups after drinking & Often & 64 & 18.1 \\
& Sometimes & 39 & 11 \\
& Never & 76 & 21.5 \\
\hline
\end{tabular}

DOI: http://dx.doi.org/10.4314/ejhs.v27i6.2 
Table 3: Prevalence of H.pylori with respect to socio-demographic characteristics of study participants attending at university of Gondar Hospital Outpatient Department, 2016.

\begin{tabular}{|c|c|c|c|c|c|c|}
\hline \multirow[t]{2}{*}{ Variables } & & \multicolumn{2}{|c|}{ H.Pylori status } & \multirow[t]{2}{*}{ Total (\%) } & \multirow[t]{2}{*}{$\mathrm{COR}(95 \% \mathrm{CI})$} & \multirow[t]{2}{*}{ P Value } \\
\hline & & Non-infected $(\%)$ & Infected (\%) & & & \\
\hline Sex & $\begin{array}{l}\text { Male } \\
\text { Female }\end{array}$ & $\begin{array}{l}98(57) \\
123(67.58)\end{array}$ & $\begin{array}{l}74(43) \\
59(32.42)\end{array}$ & $\begin{array}{l}172(48.6) \\
182(51.4)\end{array}$ & $\begin{array}{l}1.57(1.02-2.43) \\
1\end{array}$ & 0.04 \\
\hline Age & $\begin{array}{l}\leq 25 \\
26-40 \\
\geq 41\end{array}$ & $\begin{array}{l}78(59) \\
68(60.7) \\
75(68.2)\end{array}$ & $\begin{array}{l}54(41) \\
44(39.3) \\
35(31.8)\end{array}$ & $\begin{array}{l}132(37.3) \\
112(31.6) \\
110(31.1)\end{array}$ & $\begin{array}{l}1.5(0.87,2.5) \\
1.4(0.8-2.4) \\
1\end{array}$ & $\begin{array}{l}0.15 \\
0.25\end{array}$ \\
\hline Residence & $\begin{array}{l}\text { Urban } \\
\text { Rural }\end{array}$ & $\begin{array}{l}121(62) \\
100(62.9)\end{array}$ & $\begin{array}{l}74(38) \\
59(37.1)\end{array}$ & $\begin{array}{l}195(55.1) \\
159(44.9)\end{array}$ & $\begin{array}{l}1 \\
0.97(0.63-1.5)\end{array}$ & 0.87 \\
\hline $\begin{array}{l}\text { Marital } \\
\text { Status }\end{array}$ & $\begin{array}{l}\text { Married } \\
\text { Unmarried }\end{array}$ & $\begin{array}{l}124(61.7) \\
97(63.4)\end{array}$ & $\begin{array}{l}77(38.3) \\
56(36.6)\end{array}$ & $\begin{array}{l}201(56.8) \\
153(43.2)\end{array}$ & $\begin{array}{l}1.08(0.7-1.7) \\
1\end{array}$ & 0.74 \\
\hline $\begin{array}{l}\text { Educational } \\
\text { Status }\end{array}$ & $\begin{array}{l}\text { Unable to read and write } \\
\text { Primary and secondary education } \\
\text { Tertiary Education }\end{array}$ & $\begin{array}{l}82(68.9) \\
83(58) \\
56(60.9)\end{array}$ & $\begin{array}{l}37(31.1) \\
60(42) \\
36(39.1)\end{array}$ & $\begin{array}{l}119(33.6) \\
143(40.4) \\
92(26)\end{array}$ & $\begin{array}{l}0.7(0.4-1.24) \\
1.1(0.66-1.92) \\
1\end{array}$ & $\begin{array}{l}0.22 \\
0.67\end{array}$ \\
\hline Occupation & $\begin{array}{l}\text { Student } \\
\text { Farmer } \\
\text { Housewife } \\
\text { Government and Private employee } \\
\text { Others* }\end{array}$ & $\begin{array}{l}64(61) \\
35(59.3) \\
59(64.1) \\
47(61.8) \\
16(66.7)\end{array}$ & $\begin{array}{l}41(39) \\
24(40.7) \\
31(33.7) \\
29(38.2) \\
8(33.3)\end{array}$ & $\begin{array}{l}105(29.7) \\
59(16.7) \\
92(26) \\
76(21.47) \\
24(6.8)\end{array}$ & $\begin{array}{l}1 \\
1.07(0.6-2.1) \\
0.8(0.5,1.5) \\
0.96(0.5-1.8) \\
0.78(0.3-1.99)\end{array}$ & $\begin{array}{l}0.84 \\
0.5 \\
0.9 \\
0.6\end{array}$ \\
\hline $\begin{array}{l}\text { Family monthly } \\
\text { Income }\end{array}$ & $\begin{array}{l}<1000 \text { ETB } \\
1000-2999 \text { ETB } \\
>=3000 \text { ETB }\end{array}$ & $\begin{array}{l}116(64.4) \\
77(61.1) \\
28(58.3)\end{array}$ & $\begin{array}{l}64(35.6) \\
49(38.9) \\
20(41.7)\end{array}$ & $\begin{array}{l}180(50.8) \\
126(35.6) \\
48(13.6)\end{array}$ & $\begin{array}{l}0.77(0.4-1.5) \\
0.9(0.45-1.75) \\
1\end{array}$ & $\begin{array}{l}0.44 \\
0.74\end{array}$ \\
\hline Family Size & $\begin{array}{l}1-4 \\
5-6 \\
>6\end{array}$ & $\begin{array}{l}84(58.7) \\
83(69.2) \\
54(59.3)\end{array}$ & $\begin{array}{l}59(41.3) \\
37(30.8) \\
37(40.7)\end{array}$ & $\begin{array}{l}143(40.4) \\
120(33.9) \\
91(25.7)\end{array}$ & $\begin{array}{l}1 \\
0.64(0.4-1.06) \\
0.98(0.6-1.7)\end{array}$ & $\begin{array}{l}0.8 \\
0.93\end{array}$ \\
\hline
\end{tabular}

ETB: Ethiopia Birr 
Table 4: Prevalence of H.pylori with respect to socio-demographic characteristics of study participants attending at university of Gondar Hospital Outpatient Department, 2016.

\begin{tabular}{|c|c|c|c|c|c|c|}
\hline \multirow[t]{2}{*}{ Variables } & & \multicolumn{2}{|l|}{ H.pylori Status } & \multirow[t]{2}{*}{ Total n(\%) } & \multirow{2}{*}{$\begin{array}{l}\text { COR } \\
(95 \% \mathrm{CI})\end{array}$} & \multirow{2}{*}{$\begin{array}{l}\text { P- } \\
\text { Value }\end{array}$} \\
\hline & & & & & & \\
\hline \multirow{2}{*}{$\begin{array}{l}\text { Alcohol } \\
\text { Drinking habit }\end{array}$} & Yes & $108(62.8)$ & $64(37.2)$ & $172(48.6)$ & $0.97(0.63-1.49)$ & 0.89 \\
\hline & No & $113(62.1)$ & $69(37.9)$ & $182(51.4)$ & 1 & \\
\hline Type of alcohol & $\begin{array}{l}\text { Non-drinkers } \\
\text { Local alcohol } \\
\text { Beverage alcohols } \\
\text { Both }\end{array}$ & $\begin{array}{l}113(62.1) \\
77(64.7) \\
14(66.7) \\
17(53.1)\end{array}$ & $\begin{array}{l}69(37.9) \\
42(35.3) \\
7(33.3) \\
15(46.9)\end{array}$ & $\begin{array}{l}182(51.4) \\
119(33.6) \\
21(5.9) \\
32(9)\end{array}$ & $\begin{array}{l}1 \\
0.89(0.55-1.45) \\
0.82(0.32-2.13) \\
1.45(0.68-3.1)\end{array}$ & $\begin{array}{l}0.65 \\
0.68 \\
0.34\end{array}$ \\
\hline $\begin{array}{l}\text { Frequency of } \\
\text { drinking }\end{array}$ & $\begin{array}{l}\text { Non-drinkers } \\
1-3 \text { times per week } \\
\text { >3 times per week }\end{array}$ & $\begin{array}{l}113(62.1) \\
88(77.9) \\
20(51.3)\end{array}$ & $\begin{array}{l}69(37.9) \\
45(33.8) \\
19(48.7)\end{array}$ & $\begin{array}{l}182(51.4) \\
133(37.6) \\
39(11)\end{array}$ & $\begin{array}{l}1 \\
0.84(0.53-1.34) \\
1.56(0.78-3.12)\end{array}$ & $\begin{array}{l}0.46 \\
0.213\end{array}$ \\
\hline $\begin{array}{l}\text { Hand washing } \\
\text { Habit }\end{array}$ & $\begin{array}{l}\text { Either before meal or after toilet } \\
\text { Both before meal and after toilet }\end{array}$ & $\begin{array}{l}57(58.2) \\
164(64)\end{array}$ & $\begin{array}{l}41(41.8) \\
92(36)\end{array}$ & $\begin{array}{l}98(27.7) \\
256(72.3)\end{array}$ & $\begin{array}{l}1.3(0.8-2.06) \\
1\end{array}$ & 0.306 \\
\hline Source of water & $\begin{array}{l}\text { Protected pipeline } \\
\text { Protected well } \\
\text { Open water sources } \\
\text { Both protected and open source }\end{array}$ & $\begin{array}{l}103(61.7) \\
45(63.4) \\
61(65.6) \\
12(52.2)\end{array}$ & $\begin{array}{l}64(38.3) \\
26(36.6) \\
32(34.4) \\
11(47.8)\end{array}$ & $\begin{array}{l}167(47.2) \\
71(20) \\
93(26.3) \\
23(9)\end{array}$ & $\begin{array}{l}1 \\
0.93(0.52-1.65) \\
0.84(0.5-1.43) \\
1.48(0.62-3.54)\end{array}$ & $\begin{array}{l}0.804 \\
0.53 \\
0.384\end{array}$ \\
\hline $\begin{array}{l}\text { Water treatment } \\
\text { or purification }\end{array}$ & $\begin{array}{l}\text { Treated physically or chemically } \\
\text { Untreated }\end{array}$ & $\begin{array}{l}51(58.6) \\
170(63.7)\end{array}$ & $\begin{array}{l}36(41.4) \\
97(36.3)\end{array}$ & $\begin{array}{l}87(24.6) \\
267(75.4)\end{array}$ & $\begin{array}{l}1 \\
0.81(0.49-1.33)\end{array}$ & 0.4 \\
\hline
\end{tabular}


Table 5: Multivariable binary logistic regression analysis of H.pylori with the selected variables among dyspeptic patients who were attending in university of Gondar Hospital Outpatient Department, 2016

\begin{tabular}{|c|c|c|c|c|c|c|c|}
\hline \multicolumn{2}{|c|}{ Variable } & \multicolumn{2}{|c|}{ H.Pylori infection } & \multirow{2}{*}{$\begin{array}{l}\text { Total (\%) } \\
172(48.6)\end{array}$} & \multirow{2}{*}{$\begin{array}{l}\text { COR(95\% CI }) \\
1.57(1.02-2.43)\end{array}$} & \multirow{2}{*}{$\begin{array}{l}\operatorname{AOR}(95 \% \mathrm{CI}) \\
1.53(0.99-2.38)\end{array}$} & \multirow{2}{*}{$\begin{array}{l}\text { P Value } \\
0.055\end{array}$} \\
\hline Sex & Male & $\begin{array}{l}\text { Non-infected } \\
98(57)\end{array}$ & $\begin{array}{l}\text { infected } \\
74(43)\end{array}$ & & & & \\
\hline Age & $\begin{array}{l}\text { Female } \\
<=25\end{array}$ & $\begin{array}{l}123(67.58) \\
78(59)\end{array}$ & $\begin{array}{l}59(32.42) \\
54(41)\end{array}$ & $\begin{array}{l}182(51.4) \\
132(37.3)\end{array}$ & $\begin{array}{l}1 \\
1.5(0.87-2.5)\end{array}$ & $\begin{array}{l}1 \\
1.4(0.81-2.38)\end{array}$ & 0.277 \\
\hline & $\begin{array}{l}26-40 \\
>=41\end{array}$ & $\begin{array}{l}68(60.7) \\
75(68.2)\end{array}$ & $\begin{array}{l}44(39.3) \\
35(31.8)\end{array}$ & $\begin{array}{l}112(31.6) \\
110(31.1)\end{array}$ & $\begin{array}{l}1.4(0.8-2.4) \\
1\end{array}$ & $\begin{array}{l}1.37(0.79-2.39) \\
1\end{array}$ & 0.261 \\
\hline
\end{tabular}

\section{DISCUSSION}

The overall magnitude of H.Pylori infection in this study was $37.6 \%$ (95\% CI: $32.5-42.6 \%$ ) which is comparable to reports from Canada (38\%) (14) and Nepal (39\%) (15). However, the magnitude was lower that those found in studies conducted in Gondar (85.6\% and 65.7\%), Bahir Dar (61\%), Addis Ababa (81\%), Hawassa (83.3\%) and Sudan $(83 \%)(13,16-20)$. The variation in the magnitude of H.pylori might be due to differences in diagnostic methods used, living standard and risk factors across geographic location. Although the magnitude of H.Pylori is high in the study area, it was expected to be more than the observed prevalence. The universality of Proton pump inhibitor, or other drugs used by the dyspeptic patients as a treatment might have influenced the results. It seemed that patients might have difficulty of recalling the past 2 weeks drug intake which might have influenced the stool antigen test results (15). In this study, the test kits used for diagnosis of H.pylori were coated with monoclonal antibody which is specific to a single epitope of the bacterial antigen. This could have reduced the positivity of the test contributing to the lower magnitude of H.pylori in this study (21).

There are conflicting reports on the relationship between age of patients and $H$. pylori infection. Studies conducted in Bhutan by Dorji et al in 2013 (22) and in China by Zhang et al in 2013 (23) documented a comparable prevalence of H.Pylori infection with no statistically significant differences among age groups, which is in agreement with the result of our study. However, other studies found out that the prevalence of $H$. pylori increases when age advances $(13,16)$. The results of this study also showed that the magnitude of H.Pylori infection was higher in males (43\%) than in females (32\%) with no statistical association between $H$. pylori infection and sex. Likewise, a similar finding has been reported in China revealing that sex was not significantly associated with H.pylori infection (23). On the other hand, Zhu Y et al reported that the prevalence of $H$. pylori was higher in females than in males with no statistically significant differences (24). This is in contrary to a report from Canada, which found out that the magnitude was higher in males than in females. Presumably, the variation in the prevalence between males and females could be due to the difference in the lifestyles and habits such as smoking and alcohol consumption or antimicrobial use (25). In the present study, H.pylori infection has no statistical association with residence, family income, educational status, drinking and smoking habits. There was similarity in infection rate between dyspeptic patients from rural areas and urban dwellers, with no statistically significant association.

According to this study, marital status was not statistically associated with $H$. pylori infection, which is comparable with studies done in Gondar, Northwest Ethiopia (13), Ontario, Canada (25) and Yangzhong city, China (24). Contrary to our study, a study done in Lanyu Island, Taiwan (26), revealed that married individuals had shown significantly higher odds of H.pylori infection than unmarried ones. Evidences showed that marital status has shown to have an impact on

DOI: http://dx.doi.org/10.4314/ejhs.v27i6.2 
transmission of H.pylori. These evidences sugested that intrafamilial transmission plays an important role in spread of H.pylori particularly in developing countries $(27,28)$. Authors described that individuals who were married to families with gastric ulcer and lived with infected partners increased the risk of H.pylori infection (29).The reason for this discrepancy might be the difference in the sample size used-the Taiwan study used a larger sample than our study.

The findings of some authors demonstrated a negative correlation between the rate of $H$. pylori infection and the level of education (17). Our result also showed a slightly higher rate of positivity among those who are educated. Moreover, our study revealed that alcohol consumption was not statistically associated with H. Pylori infection. This is in agreement with a study done in China showing that there was no association between the prevalence of $H$. pylori infection and the use of alcohol (24).

The limitation of this study is that it is a hospital-based study. Since the infection is mostly symptomless, patients who did not visit the hospital may not be represented. Only an immunological stool antigen test method was used for the detection of $H$. pylori, which probably underestimated the prevalence of H.Pylori.

In conclusion, the magnitude of the H.Pylori infection among patients with dyspepsia in this study was high implying that it is a public health problem. Hence, the Mnistry of Health and other stakeholders should give emphasis to prevention and control measures. Moreover, communitybased screening is advisable to reduce the rate of transmission. Further community-based studies should also be conducted in the general population to understand the burden of the disease since the infection is usually asymptomatic.

\section{REFERENCES}

1. Brown LM. Helicobacter pylori: epidemiology and routes of transmission. Epidemiologic Reviews. 2000;22(2):283-97.

2. Stollman NH, Graham DY. Rallying Community Health Care Providers to Close the Gap Between H.pylori Guidelines and the
Challenges of Eradication. Gastroenterology and Hepatology. 2014;10(12):811.

3. Kusters JG, van Vliet AH, Kuipers EJ. Pathogenesis of Helicobacter pylori infection. Clinical Microbiology Reviews. 2006;19(3):449-90.

4. Correa P. Human gastric carcinogenesis: a multistep and multifactorial process-first American Cancer Society award lecture on cancer epidemiology and prevention. Cancer Research. 1992;52(24):6735-40.

5. Fox JG, Wang TC. Inflammation, atrophy, and Gastric Cancer. The Journal of Clinical Investigation. 2007;117(1): 60-9.

6. Pounder $\mathrm{R}, \mathrm{Ng} \mathrm{D}$. The prevalence of Helicobacter pylori infection in different countries. Alimentary pharmacology and Therapeutics. 1994;9:33-9.

7. Bardhan PK. Epidemiological features of Helicobacter pylori infection in developing countries. Clinical Infectious Diseases. 1997;25(5):973-8.

8. Hunt $R$, Xiao S, Megraud $F$, et al. Helicobacter pylori in developing countries. World Gastroenterology Organisation Global Guidelines. 2010, Aug: 1-5.

9. Salih BA. Helicobacter pylori infection in developing countries: the burden for how long? Saudi Journal of Gastroenterology. 2009;15(3):201.

10. De Martel C, Ferlay J, Franceschi S, et al. Global burden of cancers attributable to infections in 2008: a review and synthetic analysis. The lancet Oncology. 2012;13(6):607-15.

11. Segal I, Ally R, Mitchell H. Helicobacter pylori-an African perspective. QJM. 2001;94(10):561-5.

12. Khalifa MM, Sharaf RR, Aziz RK. Helicobacter pylori: a poor man's gut pathogen? Gut pathogens. 2010;2(1):2.

13. Moges F, Kassu A, Mengistu G, et al. Seroprevalence of Helicobacter pylori in dyspeptic patients and its relationship with HIV infection, $\mathrm{ABO}$ blood groups and life style in a university hospital, Northwest Ethiopia. World Journal of Gastroenterology. 2006;12(12):1957.

DOI: http://dx.doi.org/10.4314/ejhs.v27i6.2 
14. Sethi A, Chaudhuri M, Kelly L, Hopman W. Prevalence of Helicobacter pylori in a First Nations population in northwestern Ontario. Canadian Family Physician. 2013;59(4):e182e7.

15. Basnet B, SuperThakur S. H. pylori infection among hospital attending dyspeptic patients in Kathmandu, Nepal. Post-Graduate Medical Journal of NAMS. 2015;12(02).

16. Mathewos B, Moges B, Dagnew M. Seroprevalence and trend of Helicobacter pylori infection in Gondar University Hospital among dyspeptic patients, Gondar, North West Ethiopia. BMC Research Notes. 2013;6:346.

17. Abdallah TM, Mohammed HB, Mohammed MH, Ali AA. Sero-prevalence and factors associated with Helicobacter pylori infection in Eastern Sudan. Asian Pacific Journal of Tropical Disease. 2014;4(2):115-9.

18. Tadesse E, Daka D, Yemane D, Shimelis T. Seroprevalence of Helicobacter pylori infection and its related risk factors in symptomatic patients in southern Ethiopia. BMC Research Notes. 2014;7:834.

19. Asrat D, Nilsson I, Mengistu Y, et al. Prevalence of Helicobacter pylori infection among adult dyspeptic patients in Ethiopia. Annals of Tropical Medicine and Parasitology. 2004;98(2):181-9.

20. Tadege T, Mengistu Y, Desta K, Asrat D. Seroprevalence of Helicobacter pylori infection in and its relationship with $\mathrm{ABO}$ blood groups. The Ethiopian Journal of Health Development. 2016;19(1):55-9.

21. Wang YK, Kuo FC, Liu CJ, et al. Diagnosis of Helicobacter pylori infection: Current options and developments. World Journal of Gastroenterology. 2015;21(40):11221-35.

22. 22. Dorji D, Dendup T, Malaty HM, Wangchuk K, Yangzom D, Richter JM. Epidemiology of Helicobacter pylori in Bhutan: the role of environment and Geographic location. Helicobacter. 2014;19(1):69-73.

23. Zhang B, Hao GY, Gao F, et al. Lack of association of common polymorphisms in
MUC1 gene with $H$. pylori infection and noncardia gastric cancer risk in a Chinese population. Asian Pacific Journal of Cancer Prevention. 2013;14(12):7355-8.

24. Zhu Y, Zhou X, Wu J, Su J, Zhang G. Risk factors and prevalence of Helicobacter pylori infection in persistent high incidence area of gastric carcinoma in Yangzhong city. Gastroenterology Research and Practice. Volume 2014.

25. Naja F, Kreiger N, Sullivan T. Helicobacter pylori infection in Ontario: prevalence and risk factors. Canadian Journal of Gastroenterology and Hepatology. 2007;21(8):501-6.

26. Chen HL, Chen MJ, Shih SC, Wang HY, Lin IT, Bair MJ. Socioeconomic status, personal habits, and prevalence of Helicobacter pylori infection in the inhabitants of Lanyu. Journal of the Formosan Medical Association. 2014;113(5):278-83.

27. Raymond J, Bergeret M, Kalach N. Helicobacter pylori infection in children. Presse Med 2008;37:513-18.

28. McCallion WA, Murray LJ, Bailie AG, Dalzell AM, O'Reilly OJ, Bamford KB. Helicobacter pylori in children: Relation with current household living conditions. Gut 1996;39:18-21.

29. Brenner H, Rothenbacher D, Bode G, Dieudonne' P, Adler G. Active infection with Helicobacter pylori in healthy couples. Epidemiology and Infection. 1999;122(1):915.

DOI: http://dx.doi.org/10.4314/ejhs.v27i6.2 